\title{
BIOLOGICAL CONTROL OF BASAL STEM ROT DISEASE OF COCONUT
}

\author{
R. Bhaskaran ${ }^{1}$, N. Ramadoss ${ }^{2}$, A. Karthikeyan ${ }^{1}$ \\ and T.K. Ramachandran ${ }^{1}$
}

\begin{abstract}
SUMMARY
Trichoderma harzianum multiplied in farm yard manure and applied with neem cake to coconut palm affected by basal stem rot disease reduced the severity of the disease. Tharzianum applied in coconut basins survived for more than one year, though the population gradually declined after four months. Application of Azotobacter or phosphobacterium ( $200 \mathrm{~g}$ peat based inoculurn) to basal stern rot disease affected coconut gave lesser increase in disease index than control and increased the nut yield.
\end{abstract}

Tapping for neera production in mild and moderately diseased palms showed lesser disease index than untapped palms of corresponding disease severity.

\section{INTRODUCTION}

Basal stem rot disease of coconut hitherto called as Thanjavur wilt or Ganoderma wilt is the most serious disease limiting coconut production in Tamil Nadu, Andhra Pradesh and parts of other States in India where coconut is cultivated (Bhaskaran and Ramanathan, 1984; Nambiar and Rethinam, 1986). Ganoderma lucidurn (Leys.) Karst. was isolated from the roots of diseased palms and its pathogenicity on coconut established (Bhaskaran et al., 1992). Annual application of farm yard manure $(50 \mathrm{~kg})$ or neem cake $(5 \mathrm{~kg})$ (Bhaskaran and Ramanathan, 1983) and soil drenching with 40 litres of 1 per cent Bordeaux mixture and stern injection of Aureofungin-sol $2 \mathrm{~g}+10$ of copper sulphate in $100 \mathrm{ml}$ of water thrice at quarterly interval (Bhaskaran and Ramanathan, 1982) were found to be effective for the management of the disease. Results of the field experiments conducted on the biological control of basal stern rot disease of coconut are presented in this paper.

\section{MATERIALS AND METHODS}

\section{Effect of antagonists}

In the laboratory screening of fungi against Ganoderma lucidum for their antagonism, an isolate in each of Trichoderma harzianum arid T.viride were found to be antagonistic. These fungi were multiplied in sterilized farm yard manure (FYM) arid this inoculum was added at the rate of $500 \mathrm{~g}$ for each $50 \mathrm{~kg}$ of unsterilized FYM arid allowed for 15 days. Fifty $\mathrm{kg}$ of this manure colonised by the antagonists were applied to each diseased palm. The efficacy of the antagonists was compared with neem cake $(5 \mathrm{~kg}$ ) and the present recommendation for basal stern rot disease control (root feeding of $2 \mathrm{~g}$ of Aureofungin-sol with $1 \mathrm{~g}$ of copper sulphate in $100 \mathrm{ml}$ of water + soil drenching of 40 litres of $1 \%$ Bordeaux mixture $+5 \mathrm{~kg}$ of neem cake $(\mathrm{AF}+\mathrm{BM}+\mathrm{NC})$. FYM without antagonist served as control. Neern cake and the antagonists were applied once in a year and the fungicides thrice at quarterly interval. This experiment was initiated during December, 1987.

Microbial population in the coconut rhizosphere in the different treatments was estimated by serial dilution method employing the selective media (rose - bengal agar for fungi, soil extract agar for bacteria arid kuster's agar for actinomycetes). Trichoderm population was estimated using the

\footnotetext{
${ }^{1}$ Coconut Research Station, Veppankulam, India;

2 Tamil Nadu Rice Research Institute, India.
} 
selective medium proposed by Elad arid Chet (1983). In T.harzianum treated palms, survival of the antagonist in the rhizosphere was monitored at bimonthly interval for 12 months.

Effect of Azotobacter (A.chroococcum) and phosphobacterium (Bacillus megaterium) on basal stem rot disease was studied by applying $200 \mathrm{~g}$ of peat based inoculurn mixed with $10 \mathrm{~kg}$ of farm yard manure. The treatments were given once a year. The efficacy was compared with neem cake treatment. The biofertilizers were applied every year during July or August arid neem cake during November or December.

\section{Effect of tapping for neera:}

To find out whether tapping can be resorted to as a method of disease control, palms showing different intensity of the disease were subjected to tapping for neera production for a period of six months from September, 1987 to March, 1988. Disease intensity was recorded at the time of initiation of tapping, at the time of completion of tapping as well as one, two arid three years after completion of tapping. Nut yields during 1988 to 1990 in the experimental palms were also recorded.

Disease index in all the field experiments was recorded following the procedure of Vijayan and Natarajan (1972).

\section{RESULTS AND DISCUSSION}

In the field experiment on the efficacy of the antagonists, disease intensity recorded three years after initiation of the experiment indicated that $T$. harzianum in combination with neem cake is the most effective treatment in containing basal stem rot disease followed by $\mathrm{AF}+\mathrm{BM}+\mathrm{NC}$ treatment. $T$. viride, though effectively inhibited the growth of $G$. lucidum under in vitro conditions, was not effective under field conditions.

Rhizosphere microbial population, especially fungi and actinomycetes increased significantly in neem cake $(\mathrm{NC})$ and $\mathrm{NC}+T . h$. treatments. Bacterial population increased only marginally. Trichoderma population was more in T.h, T.v. and NC + T.h. treatments than in other treatments (Table-1). Nut yield increased in all the treatments in 1989, 1990 and 1991 when compared to the yield in 1988 except in control palms where the yield decreased from 62 nuts in 1988 to 40 nuts in 1991 due to increase in disease severity. Highest yield (95 nuts) was obtained in $\mathrm{AF}+\mathrm{BM}+\mathrm{NC}$ treatment followed by $\mathrm{NC}+T . h .(87)$ and T.h.(84) treatments.

T. harzianum when applied to the soil, maintained the population level up to fourth month and subsequently the population gradually declined in the soil recording $0.6 \times 10^{8} \mathrm{cfu} / \mathrm{g}$ of soil twelve months after inoculation. However, the population was always higher than that in uninoculated soil (Table 2).

Increase in the population of soil fungi and bacteria due to neem cake application which in turn suppressing basal stem rot severity has been reported earlier (Bhaskaran et al., 1988). Among the soil fungi, Trichoderma has been found to be more effective in containing the disease as evident from the population level and disease severity in the different treatments. Though the population of Trichoderma gradually declined in the rhizosphere over a period of 12 months, the population level was high enough to suppress the disease severity.

In the field experiment on the effect of biofertilizers on basal stem rot disease, both Azotobacter chroococcum and the phosphobacterium (Bacillus megaterium) were found to reduce the severity of the disease. Nut yield was the highest in phosphobacterium treatment followed by neem cake + Azotobacter (Table 3). Published information on the effect of Azotobacter or phosphobacteria on diseases of crop plants is scanty. Meshram and Jager (1983) reported that $A$. 
chroococcum inhibits the growth of Rhizoctonia solani by antagonism. However, in vitro studies conducted in our laboratory showed that there is no antagonism between Ganoderma lucidum and A. chroococcum or B. megaterium. The effect of these biofertilizers on disease suppression may be due to induction of host vigour by increasing nutrient availability or by induction of host resistance by altering the host physiology.

Tapping for neera production reduced the intensity of basal stem rot in ail categories of diseased palms and the effect was more pronounced in mild and moderately diseased palms than in severely diseased palms. The effect of tapping persisted even three years after completion of tapping. Anbalagan et al. (1987) reported that tapping reduced the sugar content of the palms and increased the level of total phenols. The increased phenol level may be one of the contributing factors for reduction in disease seventy in tapped palms. Tapped palms recorded markedly higher yield of nuts than the untapped palms (Table 4).

\section{ACKNOWLEDGEMENT}

The authors are thankful to the Indian Council of Agricultural Research, New Delhi for the financial assistance given through the All India Co-ordinated Research Project on Palms. 


\section{REFERENCES}

Anbalagan, R., Shanmugarn, N., Bhaskaran, R. and Vijayaraghavan, H. 1987. Biochemical constituents of coconut paims as influenced by Thanjavur wilt of coconut. In: Proc. of International Symposium on Ganoderma wilt Diseases on Palms and Other Perennial Crop (Ed.) R. Bhaskaran, Tamil Nadu Agrl. Univ., Coimbatore. pp. 17 - 18.

Bhaskaran, R., Ramadoss, N. and Ramachandran, T.K. 1988. Biological control of Thanjavur wilt disease of coconut. Indian Coconut J. 19(6): 3 - 8.

Bhaskaran, R., Ramadoss, N. and Suriachandraselvan, M. 1991. Pathogenicity of Ganoderma spp. isolated from Thanjavur wilt affected coconut (Cocos nucifera L.). Madras Agric. J. 78 (1-4). $137-138$.

Bhaskaran, R. and Ramanathan, T. 1982. Management of Thanjavur wilt of coconut. Proc. PLACROSYM V: 521 - 526.

Bhaskaran, R. and Ramanathan, T. 1983. Role of fertilizers and organic manures in Thanjavur wilt of coconut. Indian Coconut J. 14 (3): 1 - 5.

Bhaskaran, R. and Ramanathan, T. 1984. Occurrence and spread of Thanjavur wilt disease of coconut. Indian Coconut J. 15 (6): 1 - 3.

Elad, Y. and Chet, I. 1983. Improved selective media for isolation of Trichoderma spp. or Fusarium spp. Phytoparasitica $11: 55$ - 58.

Meshram, S.U. and Jager, G. 1983. Antagonism of Azotobacter chroococcum isolates to Rhizoctonia solani. Neth. J. PI.Path. 89 : 191 - 197.

Nambiar, K.K.N. and Rethinam, P. 1986. Thanjavur wilt/ Ganoderma disease of coconut. Pamphlet No. 30, Central Plantation Crops Research Institute, Kasaragod, India.

Vijayan, K.M. and Natarajan, S. 1972. Some observations on the coconut wilt disease of Tamil Nadu. Coconut Bulletin 212): 2 - 4. 
Table 1: Effec of antagonists, neem cake and fungicides on basal stem rot disease of coconut, Nut yield and rhizophere microbial population (mean of four replications)

\begin{tabular}{|c|c|c|c|c|c|c|c|c|c|}
\hline \multirow[b]{2}{*}{ Treatment } & \multirow[b]{2}{*}{$\begin{array}{l}\text { Disease } \\
\text { index }\end{array}$} & \multicolumn{4}{|c|}{ Nut yield/palm } & \multicolumn{4}{|c|}{ Microbial population (cfu/g of soil) } \\
\hline & & 1988 & 1989 & 1990 & 1991 & $\begin{array}{l}\text { Fungi } \\
\left(10^{3}\right)\end{array}$ & $\begin{array}{c}\text { Bacteria } \\
\left(10^{6}\right)\end{array}$ & $\begin{array}{c}\text { Actino- } \\
\text { Mycetes } \\
\left(10^{3}\right)\end{array}$ & Trichoderma \\
\hline $\begin{array}{l}\text { Trichoderma harzianum } \\
\text { (500 g inoculum in } 50 \mathrm{~kg} \mathrm{FYM} \text { (T.h.) }\end{array}$ & $13.9^{a}$ & $54^{b}$ & $68^{b}$ & $80^{b}$ & $84^{d}$ & $48^{c}$ & 14 & $12^{b}$ & $6 \times 107$ \\
\hline $\mathrm{T}$ viride (500g inoculum in $50 \mathrm{~kg} F \mathrm{FY}$ ) & $123.7^{\mathrm{d}}$ & $37^{a}$ & $49^{a}$ & $48^{\mathrm{a}}$ & $50^{b}$ & $50^{c}$ & 14 & $7^{a}$ & $4 \times 105$ \\
\hline Neem cake $(5 \mathrm{~kg})(\mathrm{CN})$ & $44.7^{b}$ & $36^{a}$ & $55^{a}$ & $56^{a}$ & $60^{c}$ & $51^{\text {cd }}$ & 14 & $18^{c}$ & 270 \\
\hline $\mathrm{NC}+$ T.h. & $6.9^{a}$ & $54^{b}$ & $69^{b}$ & $81^{\mathrm{b}}$ & $87^{d}$ & $56^{d}$ & 10 & $18^{\mathrm{c}}$ & $8 \times 107$ \\
\hline $\begin{array}{l}\text { Aureofungin-sol } 2 \mathrm{~g} \text { with } 1 \mathrm{~g} \text { copper sulphate in } 100 \\
\mathrm{ml} \text { water }+40 \text { litres of } 1 \% \text { Bordeaux mixture }+\mathrm{NC}\end{array}$ & $35.0^{\mathrm{ab}}$ & $64^{c}$ & $77^{c}$ & $92^{\mathrm{c}}$ & $95^{c}$ & $39^{b}$ & 18 & $15^{\mathrm{bc}}$ & 130 \\
\hline Control (FYM alone) & $89.9 c$ & $52^{c}$ & $50^{a}$ & $48^{a}$ & $40^{a}$ & $32^{a}$ & $\begin{array}{r}12 \\
\text { NS }\end{array}$ & $5^{a}$ & 70 \\
\hline
\end{tabular}

In each column figures followed by same letter do not differ significantly $(\mathrm{P}=0.05)$ according To DMRT.

NS - Not significant. 
Table 2 : Trichoderma population in inoculated and uninoculated soil.

\begin{tabular}{|lrrrrrrr|}
\hline \multirow{2}{*}{ Treatments } & \multicolumn{7}{c|}{ Months after treatment } \\
\cline { 2 - 9 } & \multicolumn{1}{c}{0} & \multicolumn{1}{c|}{ ( } & \multicolumn{1}{c|}{4} & \multicolumn{1}{c|}{6} & 8 & 10 & \multicolumn{1}{c|}{12} \\
\hline T. hariznum inoculated soil & $* 48$ & 52 & 36 & 12 & 2 & 0.8 & 0.6 \\
Control & $* * 7.8$ & 6.5 & 7.3 & 8.0 & 5.0 & 6.8 & 7.2 \\
\hline
\end{tabular}

* population expressed in $101 \mathrm{cfu} / \mathrm{g}$ of soil

**population expressed in $101 \mathrm{cfu} / \mathrm{g}$ of soil

Table 3: Effect of neem cake and biofertilizers on basal stem rot and nut yield in coconut (Mean of five replications)

\begin{tabular}{|l|r|r|r|r|r|r|}
\hline \multirow{2}{*}{ Treatments } & \multicolumn{3}{|c|}{ Disease index } & \multicolumn{3}{c|}{ Nut yield } \\
\cline { 2 - 7 } & \multicolumn{1}{|c|}{1988} & \multicolumn{1}{c|}{1989} & \multicolumn{1}{c|}{1990} & \multicolumn{1}{c|}{1989} & 1990 & \multicolumn{1}{c|}{ Mean } \\
\hline Neem cake 5kg/ palm & $27.7^{\mathrm{c}}$ & $30.4^{\mathrm{c}}$ & $56.0^{\mathrm{b}}$ & $76^{\mathrm{c}}$ & $59^{\mathrm{b}}$ & $68^{\mathrm{b}}$ \\
(NC) & $6.7^{\mathrm{ab}}$ & $8.7^{\mathrm{a}}$ & $8.9^{\mathrm{a}}$ & $63^{\mathrm{b}}$ & $90^{\mathrm{c}}$ & $77^{\mathrm{c}}$ \\
Azotobacter 200g peat \\
based inoculum (AZB) & $5.7^{\mathrm{b}}$ & $8.7^{\mathrm{a}}$ & $10.5^{\mathrm{a}}$ & $78^{\mathrm{c}}$ & $97^{\mathrm{c}}$ & $88^{\mathrm{d}}$ \\
NC+ AZB & $1.7^{\mathrm{a}}$ & $16.5^{\mathrm{b}}$ & $21.9^{\mathrm{a}}$ & $78^{\mathrm{c}}$ & $120^{\mathrm{d}}$ & $99^{\mathrm{c}}$ \\
Phosphobacterium & $9.9^{\mathrm{b}}$ & $34.3^{\mathrm{c}}$ & $92.7^{\mathrm{c}}$ & $49^{\mathrm{a}}$ & $38^{\mathrm{a}}$ & $44^{\mathrm{a}}$ \\
\hline 200g peat based inoculum & & & & \\
Control & &
\end{tabular}

In each column figures followed by same letter do not differ significantly $(P=0.05)$ according to DMRT.

Table 4: Effect of tapping for neera production on basal stem rot and nut yield in coconut (Experiment initiated in September, 1987; data are for mean of five replications)

\begin{tabular}{|c|c|c|c|c|c|c|c|}
\hline \multirow{2}{*}{$\begin{array}{l}\text { Treatments and } \\
\text { stage of the } \\
\text { disease }\end{array}$} & \multicolumn{4}{|c|}{ Disease index } & \multicolumn{3}{|c|}{ Nut vield/palm } \\
\hline & $\begin{array}{c}\text { At } \\
\text { completion } \\
\text { of tapping } \\
\end{array}$ & $\begin{array}{l}\text { One year } \\
\text { after } \\
\text { tapping }\end{array}$ & $\begin{array}{c}\text { Two years } \\
\text { after } \\
\text { tapping } \\
\end{array}$ & $\begin{array}{c}\text { Three } \\
\text { years after } \\
\text { tapping }\end{array}$ & 1988 & 1989 & 1990 \\
\hline \multicolumn{8}{|l|}{ Tapped } \\
\hline Mild & $0.92^{\mathrm{a}}$ & $1.18^{\mathrm{a}}$ & $20.45^{\mathrm{a}}$ & $26.54^{\mathrm{a}}$ & - & $102^{d}$ & $96^{c}$ \\
\hline Moderate & $3.53^{\mathrm{b}}$ & $4.68^{a}$ & $32.20^{\mathrm{a}}$ & $38.20^{\mathrm{a}}$ & - & $68^{c}$ & $64^{b}$ \\
\hline Severe & $15.86^{\mathrm{c}}$ & $21.00^{\mathrm{b}}$ & $74.80^{\mathrm{c}}$ & $93.92^{\mathrm{c}}$ & - & $38^{\mathrm{b}}$ & $30^{\mathrm{a}}$ \\
\hline \multicolumn{8}{|l|}{ Untappe (Control) } \\
\hline Mild & $6.62^{\mathrm{c}}$ & $36.75^{c}$ & $54.30^{\mathrm{b}}$ & $72.56^{\mathrm{b}}$ & 96 & $68^{c}$ & $56^{\mathrm{b}}$ \\
\hline Moderate & $5.75^{\mathrm{bc}}$ & $33.93^{c}$ & $81.44^{\mathrm{c}}$ & $96.34^{\mathrm{c}}$ & 54 & $32^{\mathrm{ab}}$ & $24^{\mathrm{a}}$ \\
\hline Severe & $9.29^{d}$ & $32.04^{\mathrm{c}}$ & $86.32^{\mathrm{c}}$ & $104.53^{c}$ & 36 & $22^{\mathrm{a}}$ & $18^{\mathrm{a}}$ \\
\hline
\end{tabular}

In each column figures followed by same letter do not differ significantly $(\mathrm{P}=0.05)$ according to DMRT. 